\title{
SCIENTIFIC
}

MUKACHEVO

STATE

Volume 8, No. 3, 9-17

Journal homepage: https://economics-msu.com.ua/en

\section{Factors of Sustainable Intensification in Agriculture of Ukraine: Evidence from the Enterprises of the Kharkivska Oblast}

\author{
Svitlana I. Strapchuk*, Olena P. Mykolenko \\ V.N. Karazin Kharkiv National University \\ 61022, 4 Svobody Sq., Kharkiv, Ukraine
}

\begin{abstract}
Reducing the negative impact of agricultural enterprises' activities on the environment with an increase in food demand can be achieved by implementing sustainable intensification measures, where the key measure is an increase in crop yields while reducing the use of resources. The purpose of this study is to identify the factors of sustainable intensification of agricultural enterprises in Ukraine by building a model of the interdependence of yield on the level of diversity of agricultural crops, application of organic fertilisers, availability of animal husbandry on the farm, labour costs, mineral fertilisers and depreciation, the use of fuel materials per 1 ha and the level of payback of costs. During the scientific study, a sample of 516 enterprises of the Kharkivska Oblast that grow agricultural products was processed; some of them are engaged in animal husbandry. Using the correlation and regression analysis method, data was analysed and processed using specialised Microsoft Excel and SPSS 21 software. The paper presents a model of the dependence of the yield of agricultural enterprises of the Kharkivska Oblast on numerous factors that were selected based on the theoretical provisions of the sustainable intensification of agriculture. It was found out that the diversity of agricultural crops, the application of organic fertilisers, the availability of animal husbandry on the farm, and labour costs are considerable factors and have both a positive and negative impact on yield. The model applied the effect of interaction between two factors, which showed the greatest impact on the dependent variable. The study provides reasoning for the availability of the highest yield among enterprises that additionally engage in economic activities for raising animals, as well as specialise in the production of various crops. The practical significance of the results obtained lies in the provision of proposals on the areas of sustainable intensification of agricultural enterprises in Ukraine
\end{abstract}

Keywords: sustainable development, circular economy, agricultural enterprises, correlation-regression model

Received: 26.04.2021, Revised: 20.06.2021, Accepted: 22.08.2021

Suggested Citation: Strapchuk, S.I., \& Mykolenko, O.P. (2021). Factors of sustainable intensification in agriculture of Ukraine: Evidence from the enterprises of the Kharkivska oblast. Scientific Bulletin of Mukachevo State University. Series "Economics", 8(3), 9-17.

${ }^{\star}$ Corresponding author 


\section{Introduction}

The world's population is constantly growing, which requires an increase in the volume of food [1]. Each country solves the problem of food security and reduces the negative impact of management on the environment in different ways. To date, several solutions have been proposed, which include constant intensification; increasing crop yields, but with less resources used $[2 ; 3]$, changing the diet $[4]$, and reducing food waste [5].

A special place among the proposed measures is occupied by increasing yields through intensification, which greatly depends on business entities and their practices. In Ukraine, intensification in agriculture is achieved in three ways: through an increase in yield per hectare, an increase in crop intensity or the use of more resources, as well as through a change in land use from low-cost crops to those that generate increased incomes and profits. Intensification in agriculture is possible under the conditions of additional application of mineral fertilisers, which increases the yield per 1 ha of land, and, often, per unit of labour used. At the same time, such intensification reduces production per unit of fertiliser applied or per unit of money invested, if other resources are not simultaneously increased (or at least optimised) in accordance with the law on reducing returns (profitability) [6]. However, for the most part, this method of management depletes land, requires a considerable amount of resources, in particular water, and has many externalities associated with a negative impact on the environment and society.

Among the promising aspects of increasing the yield, there is a steady intensification of agriculture, which is defined as the production of a greater yield from the same area of land, while reducing the negative impact on the environment and preserving natural and human capital [7].

Agricultural intensification is a method of increasing the yield per hectare, rather than expanding the area of cultivated land through better use of materials and resources [8]. The main ways to sustainably increase land productivity are to increase crop yields above the baseline level and apply the practice of double seeding. Increasingly more attention has been paid to the environmental costs of intensification over the past decade. Questions are raised as to the negative impact of fertilisers and pesticides on the environment and excessive consumption of water required for irrigation. That is why the academic and business community turned to the concept of sustainable intensification as a concept of compromise [9]. Researchers from the Netherlands found that there are not so many win-win situations in agronomy, while the trade-offs (between the resources used, the goals achieved and the values of sustainable development) are much greater [10]. Agroeconomists have defined sustainable intensification as "a simultaneous increase in the return on used land and labour (in the short term) and maintaining the balance of nutrients in the soil (in the long term)" [11]. This definition links constancy to particular business goals.
The purpose of this study is to identify the factors of sustainable intensification of agricultural enterprises in Ukraine by building a model of the interdependence of yield on the level of diversity of agricultural crops, application of organic fertilisers, availability of animal husbandry on the farm, labour costs, mineral fertilisers and depreciation, the use of fuel materials per 1 ha and the level of payback of costs.

To achieve the purpose, the study set and solved the task concerning the analysis of the influence of natural and economic factors on the yield of agricultural enterprises of the Kharkivska Oblast to establish the correlation between the indicator and a set of independent variables, considering environmental and economic components, as an attempt to expand the understanding of factors of sustainable agricultural development and their assessment.

\section{Materials and Methods}

The present study used statistical data from 516 enterprises of the Kharkivska Oblast engaged in agricultural activities, namely in the cultivation and sale of agricultural crops. Some enterprises are engaged in animal husbandry.

The following indicators were used for statistical data processing. The dependent variable in the author's model is yield, which is measured in centners per 1 ha of area, as suggested in previous models. The yield was measured as a weighted average for the crops grown by the analysed enterprises. Among the variables that affect the change in yield, the following are distinguished. The diversity of agricultural crops means the number of different types of crops grown by the enterprise. The parameter of processing areas (parts) with organic fertilisers is a dichotomous variable that takes the value 1 if there is a practice in the economic activity of the enterprise, 0 - if it is not available. The presence of animal husbandry on the farm, similar to the previous indicator, takes the value 1 if there is such a practice, 0 - if there is no practice. Remuneration of the main employees involved in the production of products is measured as a part of such expenses in the total production costs of agricultural enterprises. The use of mineral fertilisers in production is described in the author's model by a part of such costs in total production.

Additionally, control variables were used in the model, which can have different effects on yield and should be studied from the standpoint of the possibility of their constant intensification. One of these indicators is the use of fuel materials in production, which is a cost indicator per 1 ha of area. Another one - depreciation, which demonstrates the technical equipment of production, which affects the ability to increase processing and harvesting; it is measured as the share of costs in the total production costs of the enterprise and indicates the technical advantages of the enterprise in comparison with the use of manual labour. Cost recovery is the last indicator that determines the ability to return the invested funds of an enterprise, and is 
calculated in the model as the ratio of income to the cost of products sold. This indicator demonstrates the market position of the enterprise, namely price advantages.

The study uses the method of multivariate correlation and regression analysis, which allows measuring the degree of influence on the effective feature (yield) of the selected factors, establish a single measure of the tightness of the relationship and the role of the studied factors in the overall change in the effective feature. This method is used in cases where variables are not normally distributed. The paper uses a sufficient number of qualitatively homogeneous observations, in particular, their number considerably exceeds the number of factors included in the model (64 times). The main task of the method is to develop a dependence model of yield on the level of diversity of agricultural crops, the application of organic fertilisers, the availability of animal husbandry on the farm, labour costs, mineral fertilisers and depreciation, the use of fuel materials per $1 \mathrm{ha}$, and the level of payback of costs. In addition, upon constructing a correlation-regression model, the effect of interaction between the two studied factors was applied to determine their joint impact on yield. The obtained model will allow identifying and analysing the possibilities of sustainable intensification of the yield of agricultural enterprises of Ukraine using evidence from the Kharkivska Oblast.
The selection of crucial factors for inclusion in the correlation model was based on the theoretical foundations of the provisions of sustainable intensification in agriculture and pre-constructed and analysed factor groups [12; 13]. The SPSS 21 and Microsoft Excel analysis package was used to process the data and construct a linear correlation-regression model of the yield dependence on the selected factors. To exclude the problem of multicollinearity, the variance inflation factor (VIF) (multicollinearity statistics) criterion was used, which allows controlling the interchangeability of factors.

\section{Results and Discussion}

\section{Theoretical foundations of sustainable intensification}

The current intensification is based on three main assumptions: 1) the world should produce considerably more food in the coming decades to feed the growing, increasingly affluent population; 2) the area of arable land cannot be significantly expanded; 3) agricultural production should become more sustainable, and resource efficiency is the basis for preserving natural capital [12]. Table 1 describes the characteristics, principles, and practices of sustainable intensification in agriculture.

Table 1. Definition, principles, and practices of sustainable intensification in agriculture

\begin{tabular}{|c|c|c|}
\hline \multirow{5}{*}{ 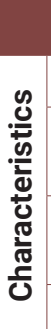 } & Sustainable intensification of agriculture & Source \\
\hline & A noticeable increase in crop production without harm to nature & J.N. Pretty [14] \\
\hline & $\begin{array}{l}\text { Maximising the return on land use and labour, ensuring a balance of soil } \\
\text { nutrients }\end{array}$ & R. Ruerd, D. Lee [11] \\
\hline & $\begin{array}{l}\text { Effective use of natural, social, and human assets, as well as the best technologies } \\
\text { that reduce the negative impact on the environment }\end{array}$ & J.N. Pretty [14] \\
\hline & Increase crop productivity to increase yields from less land & J.N. Pretty [14] \\
\hline \multirow{4}{*}{ 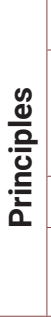 } & Use of renewable resources such as light, labour, knowledge & L.G. Firbank, J. Elliott, B. Drake [15] \\
\hline & $\begin{array}{l}\text { Efficient use of resources, optimal use of external resources, reducing the } \\
\text { negative impact of food production on the environment, reducing the yield gap }\end{array}$ & J.N. Pretty [14] \\
\hline & Use of improved varieties of agricultural crops and livestock breeds & J.N. Pretty [14] \\
\hline & Reduce food waste and increase productivity & $\begin{array}{l}\text { T. Garnett, M.C. Appleby, } \\
\text { A. Balmford [2] }\end{array}$ \\
\hline \multirow{6}{*}{ 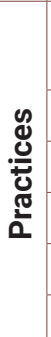 } & $\begin{array}{l}\text { Use of bio-vegetation and residual polyethylene film to cover the soil, } \\
\text { compliance with the principles of preserving tillage and crop rotation }\end{array}$ & Wezel et al. [16] \\
\hline & Inclusion of legumes and grain legumes in crop rotation & D. Tilman, C. Balzer, J. Hill [17] \\
\hline & Integrated pest management & J.N. Pretty [14] \\
\hline & Soil and water conservation, soil management & FAO [18] \\
\hline & Protection of plant genetic resources and improvement of crop varieties & FAO [18] \\
\hline & Insufficient irrigation, additional irrigation, water resources management & FAO [18] \\
\hline
\end{tabular}

Sustainable intensification is described as an agricultural process or system that supports or improves management results while preserving the environment [19]. This is a strategy for increasing labour productivity on existing agricultural land with a positive environmental and social effect [20]. That is why the intensification has also become associated with the "Green Revolution", which at the initial stage was considered as a combined use of highly productive 
varieties, mineral fertilisers and agrochemicals in the economy [21]. Later, this concept opened up new prospects for the use of "green technologies" in production.

From the standpoint of technology, productive and sustainable agricultural systems provide the best combination of different varieties of crops, livestock, and their agroecological and agronomic management [22]. Sustainable intensification requires the cultivation of complex plant and animal species adapted to local conditions and the use of appropriate management methods. The latter requires farmers to have agronomic skills and knowledge. To effectively and sustainably increase production, farmers need to understand under what conditions agricultural resources (seeds, fertilisers, and pesticides) can accelerate or, conversely, slow down biological processes in the agricultural ecosystem [23]. A separate established practice is integrated pest management, which is aimed at efficient and rational use of pesticides to restore nutrients in soils and maintain yields [23]. Management also means managing the risks associated with reduced water quality due to rapidly changing receipts of nitrogen and phosphorous fertilisers [24]. A distinctive feature of sustainable intensification is the efficient use of resources in agriculture to produce more food products with a reduced negative impact on the environment or society. The economic content of intensification lies in the development of productive forces, increasing efficiency, when new technologies and modern means of production are used in combination with scientific organisation of labour, accompanied by training of personnel and a proper level of management.

Like agricultural sustainability, resource efficiency has many dimensions: agronomic, ecological, economic, social, transgenerational, and global. That is why critics have proposed other concepts along with sustainable intensification, namely ecological intensification and agroecological intensification. The latter relates to the cultural and social aspects of the activities of agricultural enterprises [16]. Under the conditions of environmental intensification, farmers rely more on internal resources and reduce the use of external ones, which is an element of agricultural circularity [25]. The goal of environmental intensification is to use resources most efficiently, applying knowledge and better understanding of environmental processes. Environmental intensification is aimed at increasing production per unit land area while maintaining the potential of the system, which requires environmentally intensive agronomy [26] and appropriate practices. For example, a recent study in various countries has shown that crop diversification is an important tool for environmental intensification [27]. In particular, an international group of experts concluded that "diversified agroecological systems" can produce the same results as "industrial food systems" in terms of yield [28]. Consequently, the yield and its increased intensification require an analysis of the resources used in terms of their efficiency, but considering the benefits for the environment and society. Ignoring trade-offs makes intensification less sustainable, and considering them makes it more environmentally sound.

The intensification of agricultural production includes the introduction of technologies for sustainable yield growth, the use of fertilisers, additional irrigation and/or water conservation, high-performance varieties and improving crop management practices [29]. Factors of direct impact on the intensification of agriculture are as follows: labour, in the form of either human or mechanised; water, either through rain or irrigation; inorganic chemicals and/or organic substances, such as fertilisers, manure (FYM), nutrient residues and pesticides; biodiversity, whether new varieties of crops or livestock breeds [30]. Some of them were considered in the author's theoretical model. Factors that have an indirect impact on yield were also partially considered. In particular: financial capital to invest in production resources and other changes in the farming system; knowledge of a new way of working and local conditions; infrastructure that provides access to markets and production; technology that generates and supports new forms and ways of using resources; access to new markets to increase production.

\section{Selection and analysis of factors for building a model}

Thus, the data indicate that on average enterprises grow 4 agricultural crops. $11 \%$ of enterprises have areas treated with organic fertilisers and other substances, and $24 \%$ have animal husbandry on the farm, which ensures the circularity of the business model. The share of mineral fertilisers in production costs is quite high (20\% on average), which indicates the widespread use of minerals and pesticides for growing agricultural crops in the Kharkivska Oblast. The largest share of mineral fertilisers reaches $67 \%$. A low indicator on average is the share of labour remuneration in production costs $(7.31 \%)$, which is equal only for some enterprises to $10-15 \%$. A considerable number of enterprises do not have full-time employees (Fig. 1).

The amount of depreciation also indicates a small share of the cost of technical equipment in the production of agricultural goods (Fig. 1). A considerable number of enterprises do not own machinery and other fixed assets for the production of agricultural goods. 

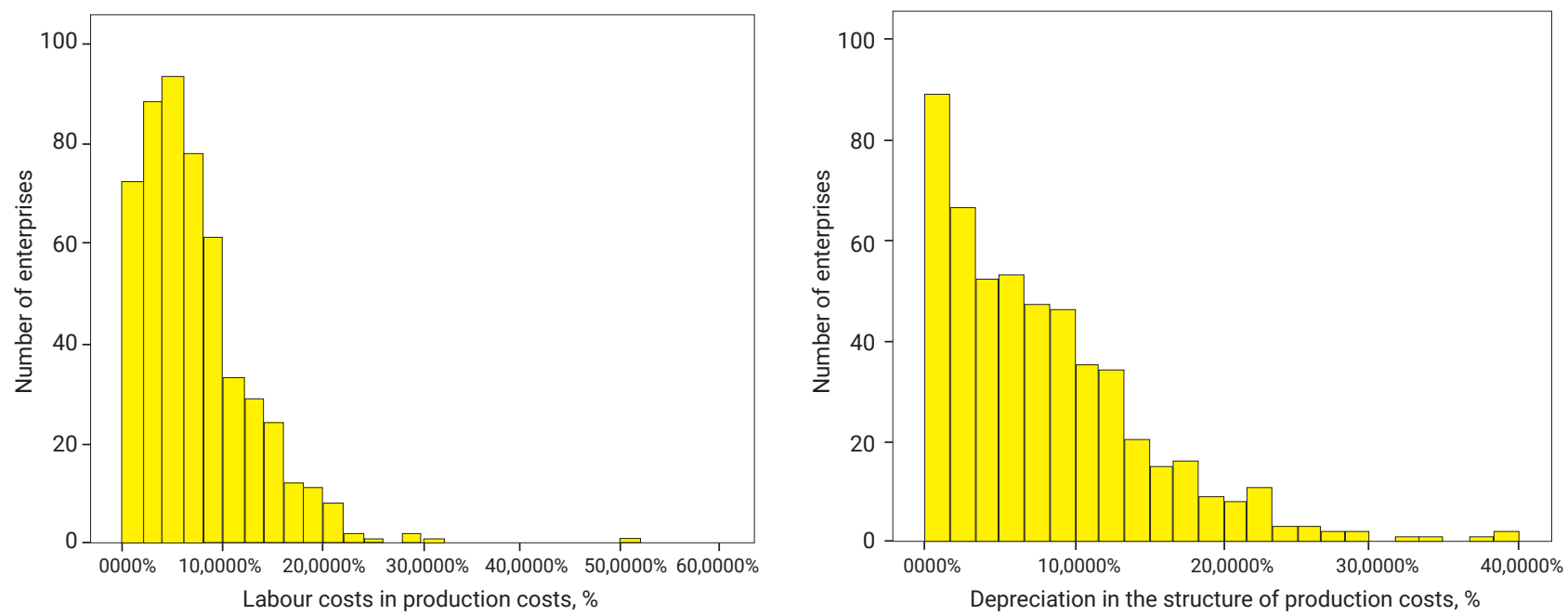

Figure 1. Labour costs and depreciation in the structure of production costs of agricultural enterprises of the Kharkivska Oblast in 2019

The average yield index for enterprises of the Kharkivska Oblast was 39.28 centners per 1 ha for those crops that are grown in the region and are the most popular on the market (Fig. 2). The cost recovery indicator demonstrates that on average, income exceeds the cost of sales by

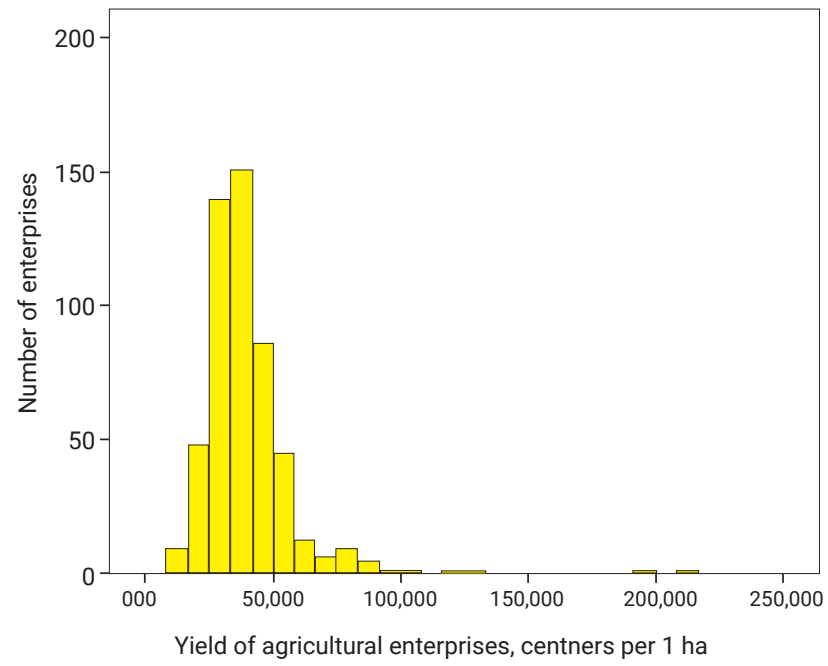

1.3, which indicates a fairly strong position in the market of agricultural enterprises. In most enterprises, this indicator does not exceed the coefficient of 2.5. The last indicator is the use of fuel and lubricants, which must be analysed in terms of cost and negative impact on the environment (Fig. 2).

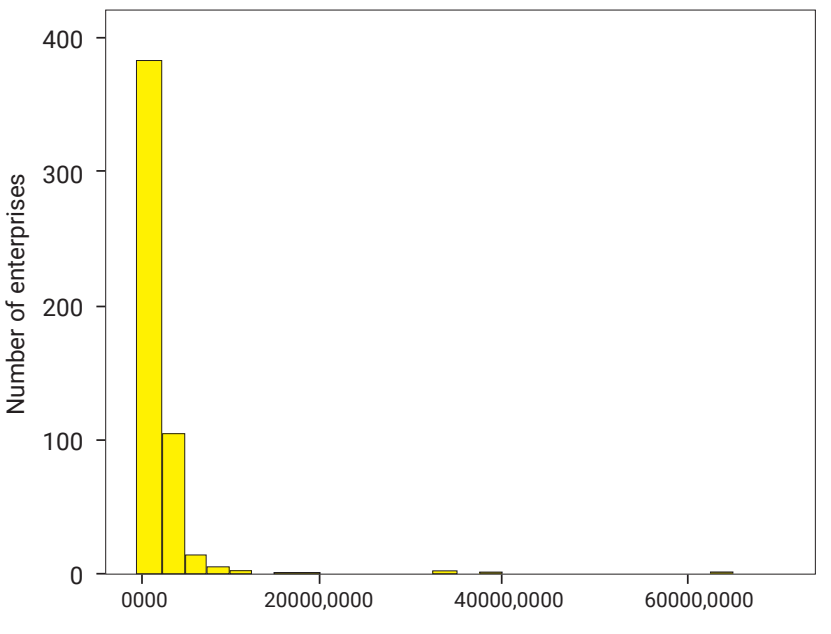

Purchase of combustible and lubrication materials, UAH per 1 ha

Figure 2. Yield and expenses for the purchase of fuel and lubricants per 1 ha of land area of agricultural enterprises of the Kharkivska Oblast in 2019

The calculation of the average value and standard the level of correlation between indicators demonstrates no deviation for all variables is presented in Table 2. Determining need to exclude indicators for further analysis.

Table 2. Descriptive statistics and analysis of correlations between yield and dependent variables

\begin{tabular}{|c|c|c|c|c|c|c|c|c|c|c|c|}
\hline Indicators & 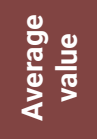 & 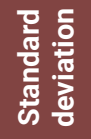 & 1 & 2 & 3 & 4 & 5 & 6 & 7 & 8 & 9 \\
\hline 1. Yield, c / ha & 39.28 & 17.58 & 1 & & & & & & & & \\
\hline $\begin{array}{l}\text { 2. Diversity of agricultural } \\
\text { crops }\end{array}$ & 4.04 & 1.73 & $0.193^{\star \star}$ & 1 & & & & & & & \\
\hline $\begin{array}{l}\text { 3. Treatment of areas (parts) } \\
\text { with organic fertilisers }\end{array}$ & 0.11 & 0.316 & 0.012 & $0.363^{\star *}$ & 1 & & & & & & \\
\hline $\begin{array}{l}\text { 4. Availability of animal } \\
\text { husbandry on the farm }\end{array}$ & 0.24 & 0.430 & $0.164^{* *}$ & $0.572^{\star *}$ & $0.383^{* *}$ & 1 & & & & & \\
\hline
\end{tabular}


Table 2, Continued

\begin{tabular}{|c|c|c|c|c|c|c|c|c|c|c|c|}
\hline Indicators & 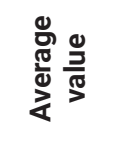 & 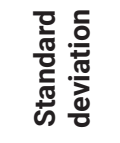 & 1 & 2 & 3 & 4 & 5 & 6 & 7 & 8 & 9 \\
\hline $\begin{array}{l}\text { 5. Labour remuneration (share } \\
\text { in production costs),\% }\end{array}$ & $7.31 \%$ & $5.72 \%$ & -0.082 & $0.353^{\star *}$ & $0.194^{\star *}$ & $0.327^{\star k}$ & 1 & & & & \\
\hline $\begin{array}{l}\text { 6. Mineral fertilisers (share } \\
\text { in production costs), \% }\end{array}$ & $19.86 \%$ & $10.07 \%$ & $0.116^{* *}$ & $-0.116^{* *}$ & -0.037 & $0.124^{\star \star}$ & $-0.280^{* \star}$ & 1 & & & \\
\hline $\begin{array}{l}\text { 7. Use of fuel materials, } \\
\text { UAH / ha }\end{array}$ & $2,407.3$ & $4,122.2$ & $0.216^{* *}$ & -0.004 & 0.062 & $0.122^{\star \star}$ & 0.035 & -0.006 & 1 & & \\
\hline $\begin{array}{l}\text { 8. Depreciation (share } \\
\text { in production costs), \% }\end{array}$ & $8.0 \%$ & $-6.9 \%$ & $0.087^{\star}$ & 0.073 & -0.020 & -0.011 & 0.022 & -0.028 & -0.047 & 1 & \\
\hline $\begin{array}{l}\text { 9. Cost recovery (ratio of } \\
\text { income and cost of sales) }\end{array}$ & 1.3 & 0.77 & $0.088^{*}$ & -0.015 & 0.072 & 0.027 & $0.109^{\star}$ & -0.003 & 0.058 & -0.047 & 1 \\
\hline
\end{tabular}

Notes: ${ }^{* *}$ - the correlation is significant at $0.01,{ }^{*}-$ the correlation is significant at 0.05

\section{Construction of a correlation-regression linear yield model}

The next stage of data analysis is the construction of a correlation-regression linear model of yield, which is reflected in Table 3.

The constructed correlation-regression linear yield model is significant $(\mathrm{F}=11.383, \mathrm{p}<0.001)$. The data indicate that all factors are significant as well, having both positive and negative effects on the dependent variable, and explaining the change in yield at the level of $13.9 \%$. In particular, the diversity of agricultural crops has a positive effect on yield; furthermore, it indicates constancy in agricultural production $(\beta=0.236, p<0.001)$. Mineral fertilisers and their use also increase yields; however, their use is limited in accordance with established production practices. The data also demonstrate that the efficiency of mineral fertilisers should increase, which requires an appropriate agricultural system for growing crops, as well as high-quality seeds, fertilisers or chemicals, and studies of the effect of their use.

Table 3. Yield model of agricultural enterprises of Kharkivska Oblast (partial model)

\begin{tabular}{lccc}
\multicolumn{1}{c}{ Indicators } & $\begin{array}{c}\text { Standardised } \\
\beta \text {-coefficients }\end{array}$ & t-coefficient & $\begin{array}{c}\text { VIF } \\
\text { (multicollinearity) }\end{array}$ \\
\hline 1. Diversity of agricultural crops & $0.236^{* *}$ & 4.502 & 1.646 \\
\hline 2. Treatment of areas (parts) with organic fertilisers & $-0.096^{*}$ & -2.117 & 1.228 \\
\hline 3. Availability of animal husbandry on the farm & $0.107^{*}$ & 2.041 & 1.643 \\
\hline 4. Labour remuneration (share in production costs), \% & $-0.173^{* *}$ & -3.745 & 1.272 \\
\hline 5. Mineral fertilisers (share in production costs), \% & $0.109^{* *}$ & 2.561 & 1.089 \\
\hline 6. Use of fuel materials, UAH / ha & $0.214^{* *}$ & 2.194 & 1.029 \\
\hline 7. Depreciation (share in production costs), \% & $0.091^{*}$ & 2.578 & 1.026 \\
\hline 8. Cost recovery (ratio of income and cost of sales) & $0.107^{* *}$ & - & - \\
\hline Constant & $21.992^{* *}$ & - & - \\
\hline F-criterion & $11.383^{* *}$ & - & - \\
\hline Adj. ${ }^{2}$ (adjusted) & 0.139 & & \\
\hline
\end{tabular}

Notes: ${ }^{* *}$ - the variable is significant at $0.01,{ }^{*}$ - the variable is significant at 0.05

Data analysis also allowed summarising that enterprises with technical advantages generate higher yields, which was repeatedly noted in the study $(\beta=0.091, \mathrm{p}<0.05)$. At present, this factor is not decisive in the yield model of enterprises that require increasing technical equipment. The cost recovery factor is significant in the model, has a positive impact on crop yields and is a sign of the constancy of enterprises' activities $(\beta=0.107, \mathrm{p}<0.01)$. Businesses with a higher ratio show better marketing policies and have a price advantage in the market. Another factor determining the positive dynamics of yield is the presence of animal husbandry as a type of activity of agricultural enterprises. The latter is a sign of the circularity of the business model, which, on the one hand, is more expensive, and on the other 
hand, increases the yield of such enterprises due to the production and introduction of additional resources, as well as the use of more efficient management methods.

At the same time, the growth of wages of key employees negatively affects the yield of agricultural enterprises in the Kharkivska Oblast, although it is an integral element of achieving sustainable practices in the sector ( $\beta=-0.173, p<0.01)$. This trend may be typical for businesses that use a lot of manual labour and demonstrate a higher salary fund. Although an increase in wages with an increase in the technical equipment of the agricultural sector may be a sign of constant intensification and have a different impact on yields, which requires further research.

A significant factor determining the yield of agricultural enterprises is the use of fuel materials $(\beta=0.214$, $\mathrm{p}<0.01)$. In this area, a compromise must be found between the volume of materials used and the adverse environmental impact. The following correlation-regression linear model demonstrates the existing effect of interaction of such factors as existing animal husbandry in agriculture and the cultivation of various agricultural crops (Table 4).

Table 4. Yield model of agricultural enterprises of Kharkivska Oblast (complete model)

\begin{tabular}{|c|c|c|c|}
\hline Indicators & $\begin{array}{l}\text { Standardised } \\
\beta \text {-coefficients }\end{array}$ & t-coefficient & $\begin{array}{c}\text { VIF } \\
\text { (multicollinearity } \\
\text { statistics) }\end{array}$ \\
\hline 1. Diversity of agricultural crops & $0.083^{*}$ & 1.312 & 2.470 \\
\hline 2. Treatment of areas (parts) with organic fertilisers & $-0.113^{\star \star}$ & -2.519 & 1.238 \\
\hline 3. Availability of animal husbandry on the farm & $0.467^{\star \star}$ & 3.193 & 13.199 \\
\hline 4. Labour remuneration (share in production costs), \% & $-0.173^{\star \star}$ & -3.805 & 1.272 \\
\hline 5. Mineral fertilisers (share in production costs), $\%$ & $0.105^{\star \star}$ & 2.490 & 1.089 \\
\hline 6. Use of fuel materials, UAH / ha & $0.242^{\star *}$ & 5.853 & 1.056 \\
\hline 7. Depreciation (share in production costs), $\%$ & $0.097^{*}$ & 2.198 & 1.015 \\
\hline 8. Cost recovery (ratio of income and cost of sales) & $0.123^{* *}$ & 3.005 & 1.035 \\
\hline $\begin{array}{l}\text { 9. Diversity of agricultural crops } \times \text { Availability of } \\
\text { animal husbandry on the farm }\end{array}$ & $0.698^{* \star}$ & 4.195 & 17.100 \\
\hline Constant & $26.751^{\star *}$ & - & - \\
\hline F-criterion & $12.405^{\star *}$ & - & - \\
\hline Adj. $R^{2}$ (adjusted) & 0.166 & - & - \\
\hline
\end{tabular}

Notes: ${ }^{* *}$ - significant at $0.01,{ }^{*}-$ significant at 0.05

In particular, the empirical model is significant $(\mathrm{F}=12.405, \mathrm{p}<0.001)$. Factors included in the model determine a positive or negative change in yield by $16.6 \%$. The complete model demonstrated that it is the effect of interaction between two certain factors that has the greatest influence. Its presence is indicated by high VIF values for these two factors studied, exceeding the values of 2 . That is, enterprises that are additionally engaged in animal husbandry, as well as grow various crops, have the highest yield $(\beta=0.698, p<0.001)$. In this model, intensification is possible, since such enterprises are more efficient in using internal resources.

Figure 3 clearly demonstrates the positive dynamics of yield growth in case of growing various crops. The exception is their number 7 , which give a reduced yield. This is conditioned upon the fact that the seventh crop of the farm, as a rule, is grasses, which themselves have a slightly lower yield than legumes. However, the increase in the number of herbs grown by the enterprise considerably increases the yield. Figure 3 also clearly demonstrates the high yield of enterprises engaged in animal husbandry. A detailed analysis requires the factor of processing land areas (parts) with organic fertilisers.

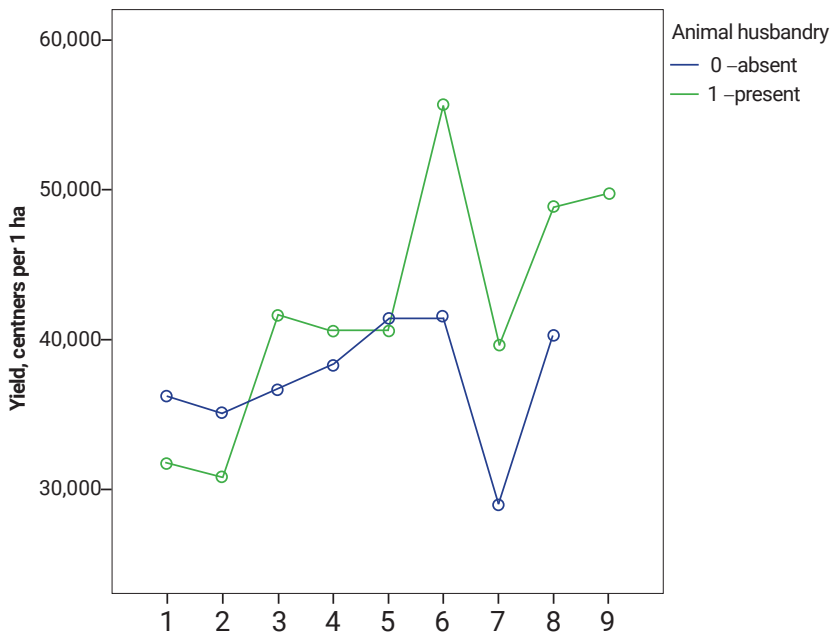

Figure 3. The effect of interaction of factors of the number of agricultural crops and the presence of animal husbandry in the management of enterprises 
Both models demonstrated that enterprises that have organic matter in their land structure show lower yields on average than those that use only mineral fertilisers and pesticides. This situation may develop solely due to the lack of special knowledge among agricultural producers about the effective use of organic fertilisers. In particular, the application of organic practices is part of environmental intensification.

\section{Conclusions}

The results of the study of the possibilities of sustainable intensification of agricultural enterprises on the example of the Kharkivska Oblast can be generalised, as evidenced by the standardised $\beta$-coefficients of the constructed models. The obtained correlation-regression models confirmed the theoretical provisions on the influence of such factors as the diversity of agricultural crops, the application of organic fertilisers, the availability of animal husbandry on the farm, labour costs and mineral fertilisers on the yield of agricultural enterprises.

The effect of the interaction of two variables allowed establishing that enterprises growing different crops and having animal husbandry are more efficient and sustainable, show higher yield indicators, and have signs of a circular business model. An increase in the use of mineral fertilisers, as well as combustible and lubrication materials, considerably affects yields, and on the way towards sustainable intensification, only a certain compromise can be found between their use (quality, quantity) and the adverse environmental impact. Increasing the level of technical equipment is an essential factor in the model, but it does not substantially affect the yield, and the cost recovery indicator indicates the importance of an effective marketing policy of enterprises.

The increased intensification of agriculture allows crop production to apply a balanced method of production without negative impact on the environment and society. The recommendation of this study is that the scientific community should focus its research strategies on developing better sustainable agricultural practices that will be adapted locally, particularly to climatic conditions.

\section{References}

[1] World population prospects. (2017). Retrieved from https://population.un.org/wpp/publications/files/wpp2017_ keyfindings.pdf.

[2] Garnett, T., Appleby, M.C., Balmford, A., Bateman, I.J., Bloomer, P., Burlingame, B., Dawkins, M., Dolan, L., Fraser, D., Herrero, M., Hoffman, I., Smith, P., Thornton, P.K., Toulmin, C., Vermeulen, S.J., \& Godfray, J. (2013). Sustainable intensification in agriculture: Premises and policies. Science, 341(6141), 33-34.

[3] Charles, H., Godfray, J., \& Garnett, T. (2014). Food security and sustainable intensification. Philosophical Transactions of the Royal Society B, 369(1639), article number 20120273.

[4] Green, R., Milner, J., Dangour, A.D., Haines, A., Chalabi, Z., Markandya, A., Spadaro, J., \& Wilkinson, P. (2015). The potential to reduce greenhouse gas emissions in the UK through healthy and realistic dietary change. Climatic Change, 129(1-2), 253-265.

[5] Gunasekera, D. (2015). Food production: Cut food waste to help feed world. Nature, 524(7566), article number 415.

[6] Keating, B.A., Carberry, P.S., Bindraban, P.S., Asseng, S., Meinke, H., \& Dixon, J. (2010). Eco-efficient agriculture: Concepts, challenges and opportunities. Crop Science, 50, 109-119.

[7] Conway, G., \& Waage, J. (2010). Science and innovation for development. London: UK CDS.

[8] Angelsen, A., \& Kaimowitz, D. (Eds.). (2001). Agricultural technologies and tropical deforestation. Wallingford: CABI Publishing.

[9] Evans, M. (2019). Agricultural intensification has fed the world, but are we healthier? Retrieved from https://forestsnews. cifor.org/59674/agricultural-intensification-has-fed-the-world-but-are-wehealthier?fnl=.

[10] Struik, P.C., Kuyper, T.W., Brussaard, L., \& Leeuwis, C. (2014). Deconstructing and unpacking scientific controversies in intensification and sustainability: Why the tensions in concepts and values? Current Opinion in Environmental Sustainability, 8, 80-88.

[11] Ruerd, R., \& Lee, D.R. (2000). Combining internal and external inputs for sustainable intensification. Retrieved from http://ebrary.ifpri.org/utils/getfile/collection/p15738coll2/id/128483/filename/128694.pdf.

[12] Cook, S., Silici, L., Adolph, B., \& Walker, S. (2015). Sustainable intensification revisited. London: IIED.

[13] Xie, H., Huang, Y., Chen, Q., Zhang, Y., \& Wu, Q. (2019). Prospects for agricultural sustainable intensification: A review of research. Land, 8(11), article number 157.

[14] Pretty, J.N. (1997). The sustainable intensification of agriculture. Natural Resources Forum, 21(4), 247-256.

[15] Firbank, L.G., Elliott, J., Drake, B., \& Cao, Y. (2013). Evidence of sustainable intensification among British farms. Agriculture, Ecosystems and Environment, 173, 58-65.

[16] Wezel, A., Soboska, G., McClelland, S., Delespesse, F., \& Boissau, A. (2015). The blurred boundaries of ecological, sustainable, and agroecological intensification: A review. Agronomy for Sustainable Development, 35, 1283-1295.

[17] Tilman, D., Balzer, C., Hill, J., \& Befort, B.L. (2011). Global food demand and the sustainable intensification of agriculture. PNAS, 108(50), 20260-20264.

[18] Thompson, P.B. (2008). The ethics of sustainable agricultural intensification. In The ethics of intensification. The international library of environmental, agricultural and food ethics (pp. 19-41). Dordrecht: Springer. 
[19] Pretty, J., Benton, T.G., Bharucha, Z., Dicks, L.V., Flora, C.B., Godfray, J., Goulson, D., Hartley, S., Lampkin, N., Morris, C., Pierzynski, G., Prasad, P.V.V., Reganold, J., Rockstrom, J., Smith, P., Thorne, P., \& Wratten, S. (2018). Global assessment of agricultural system redesign for sustainable intensification. Nature Sustainability, 1(8), $441-446$.

[20] Donovan, M. (2020). What is sustainable intensification? Retrieved from https://inlnk.ru/gozmj.

[21] Kuyper, T.W.M., \& Struik, P.C. (2014). Epilogue: Global food security, rhetoric, and the sustainable intensification debate. Current Opinion in Environmental Sustainability, 8, 71-79.

[22] Pretty, J., Toulmin, C., \& Williams, S.B. (2011). Sustainable intensification in African agriculture. International Journal of Agricultural Sustainability, 9(1), 5-24.

[23] Settle, W., \& Garba, M.H. (2011). Sustainable crop production intensification in the Senegal and Niger River basins of francophone West Africa. International Journal of Agricultural Sustainability, 9(1), 171-185.

[24] Bouwman, A.F., Beusen, A.H.W., Lassaletta, L., Apeldoorn, D.F., Grinsven, H.J.M., Zhang, J., \& Ittersum, M.K. (2017). Lessons from temporal and spatial patterns in global use of $\mathrm{N}$ and $\mathrm{P}$ fertilizer on cropland. Scientific Reports, 7, article number 40366.

[25] Levain, A., Vertès, F., Ruiz, L., Delaby, L., Gascuel-Odoux, C., \& Barbier, M. (2015). "I am an intensive guy": The possibility and conditions of reconciliation through the ecological intensification framework. Environmental Management, 56(5), 1184-1198.

[26] Struik, P.C., \& Kuyper, T.W. (2017). Sustainable intensification in agriculture: The richer shade of green. A review. Agronomy for Sustainable Development, 37, article number 39.

[27] Gurr, G.M., Lu, Z., Zheng, X., Xu, H., Zhu, P., Chen, G., Yao, X., Cheng, J., Zhu, Z., Catindig, J.L., Villareal, S., Chien, H.V., Cuong, L.Q., Channoo, C., Chengwattana, N., Lan, L.P., Hai, L.H., Chaiwong, J., Nicol, H.I., Perovic, D.J., Wratten, S.D., \& Heong, K.L. (2016). Multi-country evidence that crop diversification promotes ecological intensification of agriculture. Nature Plants, 2, article number 16014.

[28] Frison, E.A. (2016). From uniformity to diversity: A paradigm shift form industrial agriculture to diversified agroecological systems. Brussels: IPES Food.

[29] Pandey, R.K., Crawford, T.W., \& Maranville, J.W. (2002). Agriculture intensification and ecologically sustainable land use in Niger: A case study of evolution of intensive systems with supplementary irrigation. Journal of Sustainable Agriculture, 20(3), 33-55.

[30] Sustainable intensification: A new paradigm for African agriculture. (2013). Retrieved from https://inlnk.ru/poKvy.

\title{
Чинники сталої інтенсифікації у сільському господарстві України на прикладі підприємств Харківської області
}

\author{
Світлана Іванівна Страпчук, Олена Петрівна Миколенко \\ Харківський національний університет ім. В.Н. Каразіна \\ 61022, майдан Свободи, 4, м. Харків, Україна
}

Анотація. Зниження негативного впливу діяльності підприємств сільського господарства на навколишнє середовище за умови зростання потреби в продовольстві може бути забезпечене шляхом впровадження заходів сталої інтенсифікації, де ключовим вимірником є збільшення урожайності культур за умови зменшення використання ресурсів. Метою дослідження є виявлення чинників сталої інтенсифікації сільськогосподарських підприємств України шляхом побудови моделі взаємозалежності урожайності від рівня різноманіття сільськогосподарських культур, внесення органічних добрив, наявності тваринництва у господарстві, витрат на оплату праці, мінеральні добрива та амортизацію, використання паливних матеріалів на 1 га та рівня окупності витрат. Під час проведення наукового дослідження опрацьовано вибірку з 516 підприємств Харківської області, що вирощують сільськогосподарську продукцію; деякі з них займаються тваринництвом. За допомогою методу кореляційно-регресійного аналізу здійснено аналіз та обробку даних з використанням спеціалізованих програм Microsoft Excel та SPSS 21. У роботі представлено модель залежності урожайності сільськогосподарських підприємств Харківської області від низки чинників, які були обрані, спираючись на теоретичні положення сталої інтенсифікації сільського господарства. 3’ясовано, що різноманіття сільськогосподарських культур, внесення органічних добрив, наявність тваринництва в господарстві, витрати на оплату праці є значущими чинниками та здійснюють як позитивний, так і негативний вплив на урожайність. У моделі було застосовано ефект взаємодії двох чинників, який продемонстрував найбільший вплив на залежну змінну. Обгрунтовано наявність найвищої урожайності у підприємств, що додатково здійснюють господарську діяльність з вирощування тварин, а також спеціалізуються на виробництві різноманітних культур. Практична значущість отриманих результатів полягає в наданні пропозицій щодо напрямів сталої інтенсифікації сільськогосподарських підприємств України

Ключові слова: сталий розвиток, циркулярна економіка, аграрні підприємства, кореляційно-регресійна модель 